\title{
The Consumption of Bushmeat in Tombel, Southwest Region, Cameroon
}

\author{
Melle Ekane Maurice ${ }^{* 1}$, Nkwatoh Athanasius Fuashi ${ }^{1}$, Etane Sandrine Manyi ${ }^{2}$, \\ Ekabe Quenter Mbinde ${ }^{2}$ \\ ${ }^{I}$ Department of Environmental Science, University of Buea, Cameroon
}

\begin{abstract}
*Corresponding Author: Melle Ekane Maurice, Department of Environmental Science, University of Buea, Cameroon
\end{abstract}

\begin{abstract}
Bushmeat is an important source of protein and income to the local inhabitants of Tombel. With the rapid growth in human population in Cameroon, the exploitation of wildlife for bushmeat is becoming unsustainable and is threatening both the existence of wildlife populations and the livelihoods of people depending on it. The aim of this study was to examine some behaviours of the residents of Tombel on bushmeat consumption. In the course of the study about five hundred and fifty questionnaires were administered to the people of Tombel town and its neighbouring villages. The study has shown a significance on Reasons and the Seasonal consumption of bushmeat in Tombel, $X^{2}=24.3 d f=2$ at $P<0.05$, and $R^{2}=0.715$ at $P<0.05$ respectively. There was more availability of bushmeat in the dry season $51.8 \%$ than in the wet season 48.4\%. The tradition of trapping and hunting wildlife for bushmeat is facilitated by the dry forest floor of mount Kupe ecological zone. Inaddition, there was a significance between Profession and the Awareness of wildlife conservation laws $X^{2}=14.5 \mathrm{df}=3$ at $P<0.05$. Furthermore, this study revealed that despite the knowledge on wildlife restriction laws, the people of Tombel $28.3 \%$ on office workers, $27.8 \%$ on the business class, $26.8 \%$ on farmers, and $17.2 \%$ on the student population seem not to be affected by the reinforcement of the government wildlife restrictions. A decrease in hunting and trapping rate is going to increase scarcity of wildlife, hence, would discourage bushmeat consumption. Thus, the national government is recommended to create jobs for the youths so that the wildlife management in mount kupe forest should be effective.
\end{abstract}

Keywords: Bushmeat, hunting, wildlife restrictions, forest, exploitation

\section{INTRODUCTION}

Wild meat, or bushmeat, provides a major source of protein for tropical forest people around the world (Wilkie and Carpenter 1999; Bennett et al. 2007). In the Congo Basin, wild meat has been estimated to contribute between 30 to $80 \%$ of the protein intake for forest-dwelling people (Koppert et al. 1996). In rural areas with poor access to markets, wild animals often constitute the cheapest and sometimes the only type of animal protein available (Starkey 2004). However, overharvesting can affect the survival of some species, especially large-bodied, slow-reproducing taxa (Bakarr et al. 2001; Fa et al. 2002). Patterns of species extinctions have been well documented across a wide variety of islands and for a number of taxonomic groups (Sax et al. 2002). Although most island extinctions have been attributed to threats such as predation by exotic species (Blackburn et al. 2004, Sax and Gaines 2008), hunting is known to have caused the extinction of native fauna on oceanic islands worldwide ( Fitzpatrick and Keegan 2007).

Much of the current research on bushmeat in Africa focuses on West and Central Africa, and has shown that many of the findings from other areas also apply in this region, such as: the importance of bushmeat as an income source (De Merode, et al. 2004) and protein source (Vega et al, 2013); lack of sustainability of harvest rates (Barnes, 2002); the impact of bushmeat on species declines (Brashares et al, 2004); and differences in consumption between urban and rural markets (Jenkins et al, 2011). Despite the difference in ecosystem between the mainly tropical forests of Western and Central Africa and savannah, studies have shown some similarities, such as urban centres driving commercialisation of bushmeat (Lindsey et al, 2013) and reliance of rural people on bushmeat for food and income (Knapp, 2012). However, the migratory nature of many of the larger herbivores found in East Africa means that some findings are unique to 
the area, such as peak hunting in the dry season coinciding with arrival of migratory species (Holmern et al. 2007). Such fundamental ecological differences mean that it is essential to explore the context of bushmeat in an area before designing interventions to address it, with only some extrapolation of findings possible from studies based in different ecological contexts.

Lack of domestic animals and fish stock is widespread in West and Central Africa. An investigation on impact of wealth and prices on bushmeat and alternative protein consumption in Gabon revealed that rising prices of bushmeat led to less bushmeat consumption and increased consumption of fish, implying that both were dietary substitutes (Wilkie et al., 2005). Greater wealth was a significant predictor of meat consumption, though this was most pronounced when poor households experienced small increases in wealth. Households can be seen to decide whether to sell or consume a particular species, where a balance is reached between the marginal utility from consumption and the foregone net payoffs that would have resulted from a sale (Damania et al., 2005). Many of the poorest inhabitants routinely keep only the heads and intestines of meat for family consumption, but sell the more desirable meats to maximize profits. Bushmeat is often a critical component of livelihood, especially during the lean season (De Merode et al., 2004).The bushmeat commodity chain may involve professional, semi professional hunters, bushmeat as an additional source of income, and subsistence hunters who hunt for personal use (Cowlishaw et al., 2005). If not consumed by the hunter's household or given as a gift, the urban commodity chain of the bushmeat trade may involve people who transport the meat, wholesalers, people who sell the meat at market, and chopbar (café) and restaurant owners along with their employees who serve bushmeat to customers. Women are heavily involved in the transportation and sale of bushmeat. Farming of domestic animals, wildlife and fish needs to be economically feasible to represent an attractive option; even then it needs to be part of a multifaceted approach if the goal is to significantly reduce pressure on wildlife populations (Mockrin et al., 2005).The introduction of protein alternatives to diminish demand for bushmeat needs to factor in local taste preferences, cultural traditions, and political circumstances. Before advocating for protein alternatives as bushmeat alternatives in a region, household surveys can determine whether alternative sources of protein may be substitutable for bushmeat.

Among the bushmeat species consumed in Cameroon, some are on the IUCN Red List of Threatened Species (Anonyme, 2010), due to the level of uncontrolled killing in the Congo Basin. At risk mammals include, Pan paniscus, Pan t. troglodytes, Gorilla g. gorilla, diverse small monkeys of the genus Cercopithecus species complexes, and Loxodonta cyclotis. The reptile most threatened by the bushmeat trade is the dwarf crocodile, Osteolaemus tetraspis (Bene-Bene et al 2007; Wright \& Priston 2010). This also stems from other illegal practices such as traditional and commercial use of crocodile skin and elephant ivory (Chardonnet, 1995). However, the meat of these animals is also consumed when available. This situation is due to the emergence of commercial hunting which aims at satisfying the demand of urban markets but also to the lack of personnel and the inadequacy of financial and material means for those in charge of wildlife management (De Merode et al. 2007, Bennett et al. 2007). In order to reduce the pressure of hunting on the fauna, the control and management of hunting measures should be investigated, taking the season of reproduction into account. It should effectively involve local and native populations in the sustainable management of protected areas.

Bushmeat derives mainly from wildlife species, essentially mammals including species less sensitive to pressure, which should, however, be rationally exploited. In Cameroon, consumption of the three most prized orders, artiodactyls, rodents, and primates, was motivated essentially by its organic qualities and the social habits of the consumers (Mbete et al. 2010). If inhabitants of Brazzaville are allowed to consume bushmeat at the current levels, wildlife is likely to decrease and eventually to disappear. Conservation measures should take into account the interest of the population in bushmeat, and thus promote the breeding of domestic species and the breeding of animals whose meat products could be considered as "wild" by the population (blue duiker, forest buffalo, red river hog, African brush-tailed porcupine and cane rat). Such game farming already exists in the Congo Basin where cane rat, is sold at very competitive prices.

The Guineo-Congolian forests of western and central Africa are currently experiencing a 'boom' in bushmeat hunting (Barnes 2002). This traditional practice has evolved into a large-scale commercial activity due to rapid human population growth, socioeconomic change, infrastructure development and technological improvements (Bennett \& Robinson 2000). A wide variety of terrestrial vertebrates 
are consumed as bushmeat, with ungulates, rodents and primates constituting the majority ( $\mathrm{Fa}$ and Bell 2005).The current level of harvesting is deemed unsustainable; estimates suggest wildlife extraction is occurring at more than 6 times the sustainable rate (Bennett \& Robinson 2000; Bennett 2002). The long standing culture of wildlife hunting and trapping is the main supplier of bushmeat in the market, thus, the objective of this study was to examine some of the behaviours of the inhabitants of Tombel on bushmeat consumption.

\section{Materials ANd Method}

\section{Description of study site}

Tombel is located in the South West region of Cameroun. It is situated between latidude $04^{\circ} 16^{\prime}$ and $05^{\circ} 15^{\prime}$ 'north and longitude $09^{\circ} 13^{\prime}$ and $09^{\circ} 15^{\prime}$ 'East. It lies on the western side of the Kupe Mountain from where the name Kupe Muanenguba division. It covers a surface of $1007 \mathrm{Km}^{2}$ and has a population of about110 178 inhabitants (T.C, 2010). The climate of the subdivision is typical of tropical nature with all year warm temperatures, abundant rainfall, which coupled with rich soils, support rich natural forest and a wide variety of tropical crops both for local consumptions and for exportation.

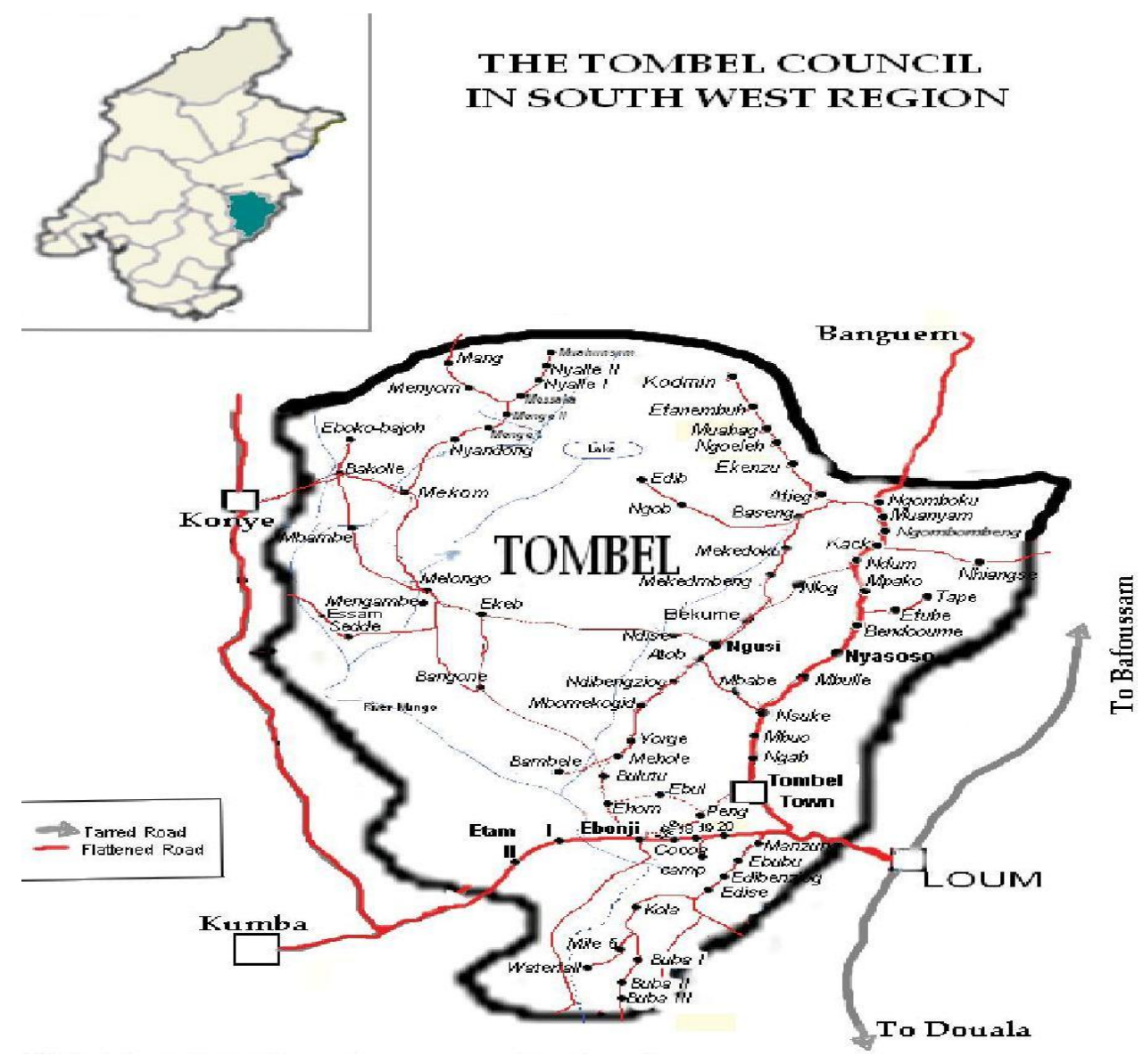

Figure 1. Map of Tombel Municipality (Source: Tombel Council, 2010)

The rainy season lasts from April to September and dry season from October to March. The soil in Tombel municipality is extremely fertile; composed of volcanic ashes. Kupe witnesses the presence of gentile slopes, deep valleys and some seasonal streams particularly "Esenze" which originates from the mount Kupe. The natural vegetation cover in Kupe village has similar characteristics with that of the dense equatorial rain forest, harboring a wide range of varieties of natural resources (T.C 2010). The area is very rich in fauna and flora. Concurrently, the type of farming method experienced in this area has changed some part of the forest into a savannah type. There is a large forest around Tombel town, but the disappearance of forest is causing population reduction of wildlife species such as Chimpanzee (Pan troglodytes), Drill (Mandrillus leucophaeus), Red Colobus (Phylocolobus preussi), Mangabey(Cercocebus torquatus), Crown Monkey (Cercopithecus pongonia), Mona Monkey (Cercopithecus mona), Preuss Monkey (Cercopithecu spreussi), Putty Nosed Monkey (Cercopithecus 
nictitans), Red Eared Monkey(Cercopithecus erythrotis), Tantalus (Cercopithecus tantalus), Cane Rat (Thryonomys swinderianus), Giant Rat (Criceetomys spp.), Porcupine (Antherurus africanus), African Civet (Civettictis civetta), Pangolin (Manis spp), Red River Hog (Potamochoerus porcus), Red Duikers (Cephalophus spp.), Blue Duiker (Cephalophus monticola), Black Snake (Naja spp.), Monitor Lizard (Veranus niloticus), Python (Python sebae), and Viper (Bitis gabonica) (T.C 2010).

\section{Data collection and analysis}

Data were collected in the month May 2017, just after a pilot survey was conducted to test this method, questionnaires administration was done alongside the oral interview to five hundred and fifty inhabitants of Tombel. These instruments were used to collect both quantitative and qualitative data to safeguard the purpose of triangulation and complementation. Since the issue of bushmeat is becoming more sensitive to the wildlife management authorities in Cameroon, a mixed method approach was used to triangulate findings, as recommended by Gavin et al. (2010). The work was done with the help of two local field assistants. The field assistants helped in the local dialect communication translation between the researcher and the respondents whenever necessary. The administration of questionnaires and the oral interview was done in five different areas chosen by sampling and deemed to potentially have more variation in opinions, and more participant availability. Quantitative and qualitative data collected from the respondents was coded according to various variables and organized for computer analysis using SPSS Version 20.0. Analysis of this data included running of descriptive statistics such as frequency distribution and results presented in tables and pie charts, while the inferential statistical analysis done used chi-square and correlation models.

\section{Results}

The study has shown in figure 2 and figure 3 a significance on Reasons and the Seasonal consumption of bushmeat in Tombel, $\mathrm{X}^{2}=24.3 \mathrm{df}=2$ at $\mathrm{P}=0.000$, and $\mathrm{R}^{2}=0.715$ at $\mathrm{P}<0.05$ respectively. Inaddition, there was a significance between Profession and the Awareness of wildlife conservation laws $\mathrm{X}^{2}=14.5 \mathrm{df}=3$ at $\mathrm{P}<0.05$ (fig.4). There was more availability of bushmeat in the dry season $51.8 \%$ than in the wet season $48.4 \%$. The tradition of trapping and hunting wildlife for bushmeat seems to have been facilitated by the dry forest floor of mount Kupe ecological zone. During this period the wildlife concerntrate more on their trails towards the rivers, streams, and springs, a behaviour well understood by the trappers and the poachers. The hunting and trapping of wildlife is focused more on these areas where the animals are easily preyed upon. This is the main reason of the increase of bushmeat availability in Tombel area. But during the rainy season the wildlife seems not to have a specific target area for hunting and trapping, secondly, the rain prevents many hunters and trappers from exploiting the forest to maximum. This seems to reduce the population of wildlife killed for bushmeat consumers.

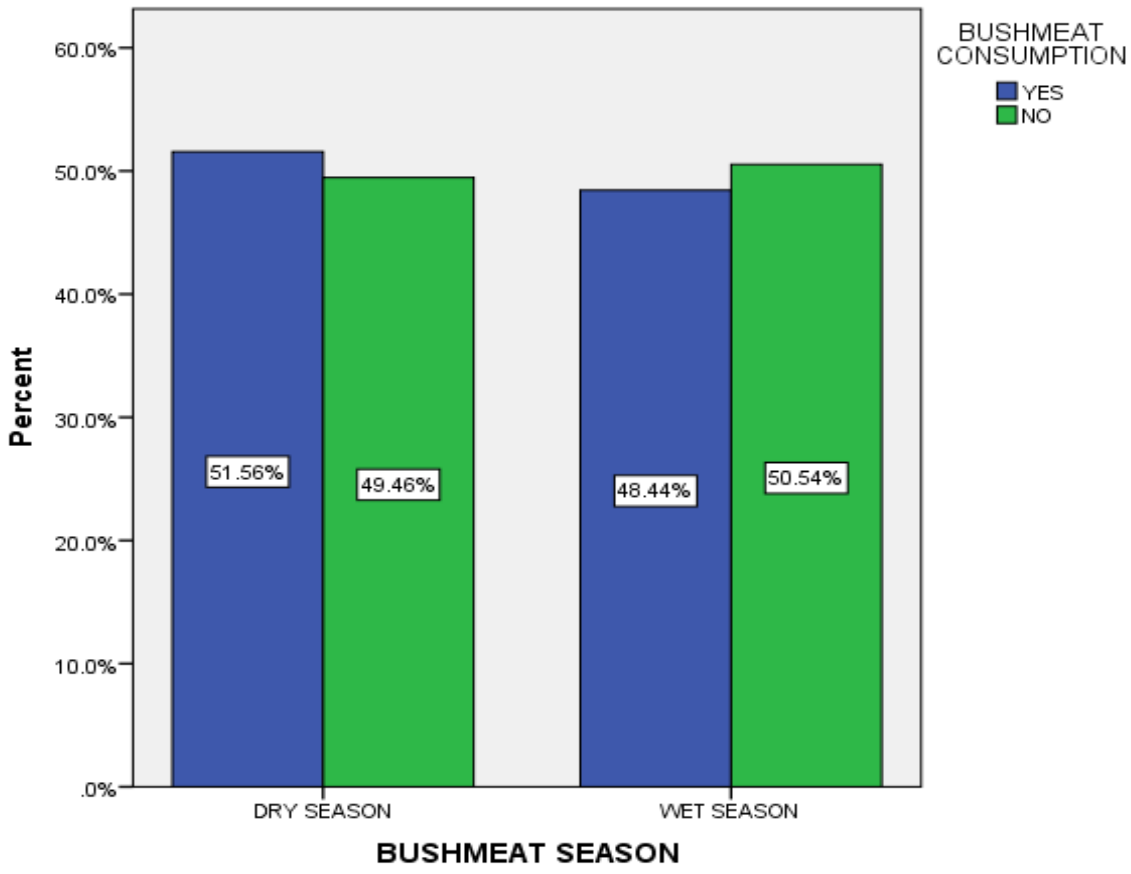

Fig 2. Bushmeat consumption season 

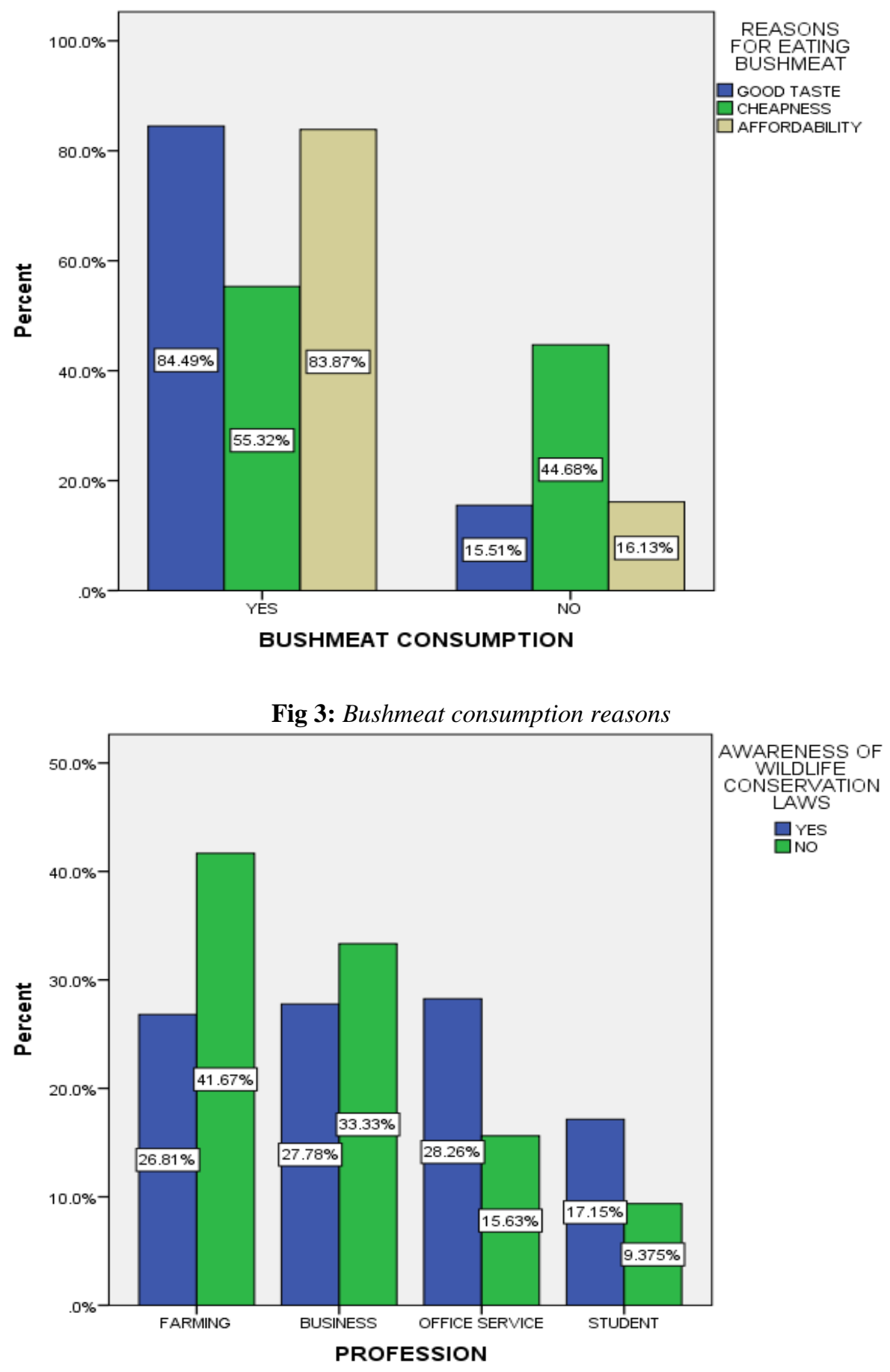

Fig 4: Profession and the awareness of wildlife conservation laws

The office workers in Tombel are educated and seem to have a reading behaviour more than any other professional inhabitants of the area. Their ability to have a higher knowledge background on wildlife conservation laws $28.26 \%$ is because they have more access to news papers and books where they read about wildlife conservation laws (fig.4). Tombel is known to have a relatively high population of teachers from Primary to High Schools forming the bulk of the professional workers in the area.

\section{DISCUSSION}

Bushmeat is known as an important protein source and income in so many areas in the tropics, where there are often few alternatives. However, due to the human population increase, such exploitation is becoming unsustainable and is threatening both the existence of wildlife populations and the livelihoods of people depending on it. Though, the causes of wildlife population reduction is very well understood, acting upon this understanding is often difficult, due to the complex range of interacting factors. Biodiversity concentration is found in the tropics, an area which home many of the world's poorest people. This juxtaposition means that many in the tropics are directly 
reliant on natural resources for their survival (USAID, 2006; Kalaba \& Dougill, 2013) and, with growing populations (World Bank, 2014a), resources are being exploited unsustainably. The results of this survey have shown that bushmeat is a source of food, $84.5 \%$ on taste, $83.9 \%$ on affordability, and $55.3 \%$ on cheapness (fig.2). All the Tombel inhabitants seem to be having a craving love for bushmeat despite the national Government illegal hunting and poaching restrictions. The growing scarcity of bushmeat in Tombel market might not only be based on the Government restrictions and ban on endangered wildlife species but might also be because of the high demand for its consumption. Bushmeat is an important food source for people in developing countries (Fa \& Meeuwig, 2002; Rentsch \& Damon, 2013) and a valuable source of protein and fats in many rural diets (Bennett \& Robinson, 2000); estimates of bushmeat consumption for the Amazon and Congo basins lie at over 5 million tons of meat annually, or $282.3 \mathrm{~g} /$ person/day. The importance of bushmeat as a food source for rural people is matched by its importance as an income source (De Merode, et al ,2004; Brown \& Marks, 2005), with hunting of bushmeat often a major proportion of income generation for the poorest households (Kümpel et al, 2010). Conversely, in some situations bushmeat consumption increases with household income, because it is preferred over domestic livestock protein (Jenkins et al, 2011). This has been attributed to an "inverted U pattern" of demand in relation to income, with a peak in demand for bushmeat at middle income range, then a decrease when more expensive domestic meats become affordable with higher income (Wilkie \& Godoy, 2001). Another explanation for this apparent contradiction is proximity to urban centres, with households closer to urban areas increasing bushmeat consumption with income, and vice versa (Brashares et al, 2011).

Bushmeat consumption in Sub-saharan African Region is an old tradition, very difficult to overcome by wildlife conservation regulations at all governmental levels. The management of wildlife in the conserved areas has faced a lot of challenges over many decades. Majority of the inhabitants in these conservation areas are poor. Thus, wildlife meat is considered as a source of livelihood to these people. Inaddition, the bushmeat consumption long standing tradition of Tombel people in particular is recently focused on the good taste by its consumers (fig.3). Even those who can afford the alternative source of protein or domestic meat still count so much on the bushmeat for its good taste. According to Schenck et al, (2006) rural participants in a taste test in Gabon showed consistent preference for bushmeat compared to urban participants Urban consumers in Equatorial Guinea (East et al, 2005), Zambia and Mozambique ( Rob Barnett, 1997) prefer the taste of bushmeat to domestic meat. Conversely, in rural areas the lower price of bushmeat drives demand, rather than taste (Barnett, 1997; Lindsey et al, 2010; Lindsey et al, 2011). Bushmeat hunting and consumption can also have a cultural aspect, such differences in bushmeat consumption between different ethnic groups (Ceppi \& Nielsen, 2014). However, it should be noted that some differences which are initially perceived as due to cultural factors may instead be explained by proximity to infrastructure such as roads, or the distance to areas of wildlife. Other cultural aspects can include use in traditional ceremonies, such as male circumcision ceremonies in Gabon (Van Vliet \& Nasi, 2008).

This study has shown that despite the knowledge on wildlife restriction laws the people of Tombel $28.3 \%$ on office workers, $27.8 \%$ on the business class, $26.8 \%$ on farmers, and $17.2 \%$ on the student population, there seems to be no sign of compliance to the restrictions (fig.3). Unfortunately, the killing of wild animals has been restricted in many areas in Cameroon but already prepared bushmeat sold in restaurants and individual homes is still far from facing restrictions. Bushmeat is widely recognised as an important source of protein in the Congo Basin (Fa et al. 2003). It is usually the most available in rural communities and often the most preferred (Schenck et al. 2006). On average in Cameroon, bushmeat supplies $26 \mathrm{~g}$ of daily protein intake per person, equivalent to half the recommended daily protein requirement ( $\mathrm{Fa}$ et al. 2003). Based on average weekly consumption estimates provided by interviewees rather than actual protein intake data, bushmeat appears to be the animal protein consumed most frequently by harvesters in Lebialem in Cameroon.

\section{CONCLUSiON}

The hunting and trapping of wildlife for bushmeat consumption in Tombel area has very much increase in the recent years. This increase is believed to be due to the high unemployment rate in the entire country. The middle age population in this area is known to be very educated, but due to unemployment, these youth are returning home from urban cities after their university education for 
less professional jobs like hunting and trapping of the wildlife, a source of livelihood. The national government regulations preventing the hunting and trapping of wildlife seems to yield very little success, since it has to do with poverty of the local inhabitants of Tombel. This study strongly recommends that the national government should create jobs for the youths in Tombel in order to distract them from the illegal hunting and trapping of wildlife for bushmeat marketing. Though, the government wildlife authorities might be claiming that the wildlife population is increasing in the forest of mount kupe, however, any comprehensive wildlife population inventory carried out might discover that the wildlife species have reduced in population and some even extirpated.

\section{REFERENCES}

Anonyme, 2010. Carte d'Afrique avec pays, capitales d'Afrique www.afriqueindex.com/.../carte-afrique.htm-. Consulté le 16/07/2010.

Bakarr, M., W. Oduro, and E. Odomako. 2001. West Africa: regional overview of the bushmeat crisis. Pages 110-114 in N. D.Bailey, H. E. Eves, A. Stefan, and J. T. Stein, editors. Bushmeat crisis task force collaborative action planning meeting proceedings.Bushmeat Crisis Task Force, Silver Spring, Maryland, USA.:

Barnes, R.F.W. 2002. The bushmeat boom and bust in West and Central Africa. Oryx 36(3), 236-242.

Bene-Bene L., De Semboli B., Mbenzo V., S'hwa D., Bayogo R., Williamson L., Fay M., Hart J. and Maisels F. 2007. Forest Elephant Crisis in the Congo Basin. Plos Biology 4 (5): 945-953.

Bennett, E.L. (2002) Is there a link between wild meat and food security? Conservation Biology. 16 (3), 590592.

Bennett, E. L., and J. G. Robinson. 2000. Hunting of wildlife in tropical forests: implications for biodiversity and forest peoples. World Bank, Washington, D.C., USA

Bennett, E.L., Blencowe, E., Brandon, K., Brown, D., Burn, R.W., Cowlishaw, G., Davies, G., Dublin, H., Fa, J.E., Milner-Gulland, E.J., Robinson, J.G., Rowcliffe, J.M., Underwood, F.M., and Wilkie, D.S. 2007. Hunting for Consensus: reconciling bushmeat harvest, conservation, and development policy in West and Central Africa. Conservation Biology 21(3): 884- 887.

Blackburn, T. M., P. Cassey, R. P. Duncan, K. L. Evans, and K.J. Gaston. 2004. Avian extinction and mammalian introductions on oceanic islands. Science 305:1955-1958.

Brashares, J. S., C. D. Golden, K. Z. Weinbaum, C. B. Barrett,and G. V. Okello. 2011. Economic and geographic drivers of wildlife consumption in rural Africa. Proceedings of the National Academy of Sciences 108:13931-13936

Brashares,J.S. Arcese P.Sam M.K.Coppolillo, P.B.Sinclair A.R.E.\& Balmford,A.(2004) Bushmeat Hunting, Wildlife Declines, and Fish Supply in West Africa.Science,306, 1180-1183.

Brown, T. \& Marks, S.A. (2007) Livelihoods, Hunting and the Game Meat Trade in Northern Zambia. In: Glyn Davies \& David Brown (eds.). Bushmeat and Livelihoods: Wildlife Management and Poverty Reduction. [Online]. Oxford, UK, Blackwell Publishing Ltd. pp. $92-105$.

Ceppi, S.L. \& Nielsen, M.R. (2014) A comparative study on bushmeat consumption patterns in ten tribes in Tanzania. Tropical Conservation Science. 7 (2), 272-287.

Chardonnet P. 1995. Faune sauvage africaine. La ressource oubliée. Luxembourg: Commission européenne 1: $416 \mathrm{p}$

Cowlishaw, G.,Mendelson, S., and Rowcliffe, J.M. 2005. Structure and operation of a bushmeat commodity chain in southwestern Ghana. Conservation Biology 19(1): 139-149.

Damania, R., Milner-Gulland, E.J., and Crookes, D.J. 2005. A bioeconomic analysis of bushmeat hunting. Proc. R. Soc. B 272: 259-266.

De Merode, E., Homewood, K., and Cowlishaw, G. 2004. The value of bushmeat and other wild foods to rural households living in extreme poverty in Democratic Republic of Congo. Biological

De Merode E., Smith K.H., Homewood K., Pettifor R., Rowcliffe J.M. and Cowlishaw G. 2007. The impact of armed conflict on protected-area efficacy in Central Africa. Biology Letters 3 (3): 299-301. Google Scholar Conservation 118: 573-581.

East,T., N. F. Kümpel, E. J. Milner-Gulland, and J .M. Rowcliffe.2005. Determinants of urban bushmeat consumption in Río Muni, Equatorial Guinea. Biological Conservation126:206-215

Fa, J.F. and Bell, D.J. 2005. Hunting vulnerability, ecological characteristics and harvest rates of bushmeat species in afrotropical forests. Biological Conservation 121: 167-176. 
Fa,J.E.,Peres,C.A.\& Meeuwig,J.(2002) Bushmeat Exploitation in Tropical Forests: an Intercontinental Comparison. Conservation Biology,16,232-237.

Fa, J.E., Currie, D., and Meeuwig, J. 2003. Bushmeat and food security in the Congo Basin: linkages between wildlife and people's future. Environmental Conservation 30(1): 71-78

Fitzpatrick, S. M., and W. F. Keegan. 2007. Human impacts and adaptations in the Caribbean islands: an historical ecology approach. Earth and Environmental Science Transactions of the

Gavin, M.C., Solomon, J.N. \& Blank, S.G. (2010) Measuring and monitoring illegal use of natural resources. Conservation Biology. [Online] 24 (1), 89-100.

Holmern, T., Muya, J. \& Røskaft, E. (2007) Local law enforcement and illegal bushmeat hunting outside the Serengeti National Park, Tanzania. Environmental Conservation. [Online] 34 (01), 55-63.

Jenkins, R. K. B.,A. Keane, A. R.Rakotoarivelo,V. Rakotomboavonjy, F. H. Randrianandrianina, H. J. Razafimanahaka, S. R. Ralaiarimalala, and J. P. G. Jones. 2011. Analysis of patterns of bushmeat consumption reveals extensive exploitation of protected species in eastern Madagascar.

Kalaba, F.K., Quinn, C.H. \& Dougill, A.J. (2013) The role of forest provisioning ecosystem services in coping with household stresses and shocks in Miombo woodlands, Zambia. Ecosystem Services. [Online] 5143148. Available from: doi:10.1016/j.ecoser.2013.07.008.

Koppert, G., E. Dounias, A. Froment, and P. Pasquet. 1996. Consommation alimentaire dans trois populations forestières de la région côtière du Cameroun: Yassa, Mvae et Bakola. Pages 477-495 in C. M. Hladik, A. Hladik, H. Pagezy, O. F. Linares, G. J. A. Koppert, and A. Froment, editors. L'alimentation en forêt tropicale, interactions bioculturelles et perspectives de développement. Volume I, Les ressources alimentaires : production et consommation, UNESCO, Paris, France.

Knapp, E.J. (2012) Why poaching pays: A summary of risks and benefits illegal hunters face in Western Serengeti, Tanzania. Tropical Conservation Science. 5 (4), 434-445.

Kümpel N.F., Milner-Gulland E.J., Cowlishaw G. and Rowcliffe J.M. 2010. Incentives for Hunting: The Role of Bushmeat in the Household Economy in Rural Equatorial Guinea. Human Ecology 38 (2):251-264.

Lindsey, P.A., Romañach, S.S., Matema, S., Matema, C., et al. (2011) Dynamics and underlying causes of illegal bushmeat trade in Zimbabwe. Oryx. [Online] 45 (01), 84-95.

Lindsey, P.A., Balme, G., Becker, M., Begg, C., et al. (2013) The bushmeat trade in African savannas: Impacts, drivers, and possible solutions. Biological Conservation. [Online] 16080-96.

Mbete P., Ngokaka C., Akouango F., Bonazebi N. and Vouidibio J. 2010. Evaluation des quantités de gibiers prélevées autour du Parc National d'Odzala-Kokoua et leurs impacts sur la dégradation de la biodiversité. Journal of Animal \& Plant Sciences. 8 (3): 1061-1069.

Mockrin, M.H., Bennett, E.L., LaBruna, D.T. 2005. Wildlife farming: a viable alternative to hunting in tropical forests? WCS Working Paper 23.

Rentsch, D. \& Damon, A. (2013) Prices, poaching, and protein alternatives: An analysis of bushmeat consumption around Serengeti National Park, Tanzania. Ecological Economics.

Rob Barnett (ed.) (1997) Food for Thought: The Utilisation of Wild Meat in Eastern and Southern Africa. Nairobi, TRAFFIC

Sax, D. F., S. D. Gaines, and J. H Brown. 2002. Species invasions exceed extinctions on islands worldwide: a comparative study of plants and birds. American Naturalist160:766-783.

Schenck M., Effa-Nsame E., Starkey M., Wilkie D., Abernethy K., Telfer P., Godoy R. and Treves A. 2006. Why People Eat Bushmeat: Results From Two-Choice, Taste Tests in Gabon, C

Tombel Council (2010). The Tombel Council Report

USAID (2006) Issues in Poverty Reduction and Natural Resource Management . Washington DC, USAID

Van Vliet, N. \& Nasi, R. (2008) Hunting for livelihood in Northeast Gabon: Patterns , evolution , and sustainability. Ecology and Society. 13 (2), 33.

Vega, M.G., Carpinetti, B., Duarte, J. \& Fa, J.E. (2013) Contrasts in livelihoods and protein intake between commercial and subsistence bushmeat hunters in two villages on Bioko Island, Equatorial Guinea. Conservation Biology. [Online] 27 (3), 576-587.

Wilkie, D. S., and J. F. Carpenter. 1999. Bushmeat hunting in the Congo Basin: an assessment of impacts and options for mitigation. Biodiversity and Conservation 8:927-955. http://dx. 
Wilkie,D.S. \& Godoy,R.A. (2001) Income and Price Elasticities of Bushmeat Demand!in Lowland Amerindian Societies. Conservation Biology,15,761-769.

Wilkie, D.S., Starkey, M., Abernethy, K., Effa, E.N., Telfer, P., and Godoy, R. 2005. Role of prices and wealth in consumer demand for bushmeat in Gabon, Central Africa. Conservation Biology 19(1): 268-274.

World Bank (2014a) Fertility rate, total (births per woman). [Online]. 2014. Available from: http://data.worldbank.org/indicator/SP.DYN.TFRT.IN/countries?display=map

Wright J.H. and Priston N.E.C. 2010. Hunting and trapping in Lebialem Division, Cameroon: bushmeat harvesting practices and human reliance. Endangered Species Research 11: 1-12.

Citation: Melle E. M. et al., " The Consumption of Bushmeat in Tombel, Southwest Region, Cameroon ", International Journal of Research in Environmental Science, vol. 3, no. 4, p. 8-16, 2017. http://dx.doi.org/10.20431/24549444.0304002

Copyright: () 2017 Authors. This is an open-access article distributed under the terms of the Creative Commons Attribution License, which permits unrestricted use, distribution, and reproduction in any medium, provided the original author and source are credited. 